\title{
An Online 2+2 Bachelor's Degree Program Track in Industrial Engineering at Lamar University
}

Dr. James C. Curry, Lamar University

Dr. James Curry is an Associate Professor in the Lamar Industrial Engineering department.

\section{Dr. Brian Craig P.E., Lamar University}

Dr. Brian Craig, PE, CPE is a Professor and the Chair of the Department of Industrial Engineering at Lamar University. He is a Registered Professional Engineer in the State of Texas and a Certified Professional Ergonomist. He has published over 40 journal articles, textbook chapters, conference proceedings, and industrial technical papers as well as presented in numerous national research conferences. He has been involved in 26 (22 as PI) industry and governmental supported research projects totaling over $\$ 1.4 \mathrm{M}$, mostly in the maritime industry. Dr. Craig is the Director of the Mariner Safety Research Initiative at Lamar, the Interim Director of the Center for Advances in Port Management, and a University Scholar.

\section{Prof. Weihang Zhu, Lamar University}

Weihang Zhu is an Associate Professor of Industrial Engineering, Lamar University, USA since 2005. He received his Ph.D. in Industrial Engineering from North Carolina State University (2003), USA and his M.S. (2000) and B.S. (1997) in Mechanical and Energy Engineering at Zhejiang University, China. His research interests include Engineering Education, Computer haptics, CAD/CAM, high performance computing, meta-heuristics, multi-axis NC surface machining. 


\title{
An Online 2+2 Bachelor's Degree Program Track in Industrial Engineering at Lamar University
}

\author{
James Curry, Brian Craig, Weihang Zhu \\ Department of Industrial Engineering, Lamar University, Beaumont, TX, USA
}

\begin{abstract}
This paper reports a 2+2 Bachelor's Degree in Industrial Engineering (BSIE) online option at Lamar University (LU), first launched in fall 2014 after ABET's vote to continue the program's accreditation in light of this online program option. It is the first BSIE $2+2$ online program in the country. Students may choose to complete their first two years' regular fundamental courses at $\mathrm{LU}$, at a community college or other university. Then they may choose to complete the last two years at LU via distance education. All online courses are delivered and managed through the Blackboard system. Some courses are currently under review by the rigorous 'Quality Matters' standard and as an objective, all courses will need to pass the standard requirement. Several courses have lab requirements. Some labs, such as Work Design, were converted to video-based labs; while for other labs, such as Manufacturing Processes, students come to campus for one or two long weekend labs during the program. The courses' labs that require software such as PTC Creo and Rockwell Arena are administered interactively in real time via Adobe Connect. Students can access the professional version of the campus software via a Remote Desktop system. The senior design course is a project based class with the same structure as our face to face track. This program provides a unique pathway for completing an engineering degree that allows students who cannot attend full time due to work, location and family responsibilities to complete an engineering degree. While a significant number of students attend pre-engineering programs at community colleges, the number of students who are interested and capable of completing an online program is significantly less. A second population of students who drop out of engineering programs for work or family reasons after completing sophomore courses also has interest in this program. In addition to presenting the program design and operation, this paper discusses the potential market for the program nationwide, preliminary student performance, and the results of a faculty survey about online courses.
\end{abstract}

\section{Program Overview}

Beginning in the fall 2014, the Industrial Engineering (IE) department at Lamar University (LU) began offering a BSIE degree in a $2+2$ online format. The goal of the $2+2$ online option is to reach capable students who are unable to complete a traditional engineering program due to location and time of day restrictions. The $2+2$ format has students take the first two year using traditional instruction at $\mathrm{LU}$, another university, or community college. The last two years can be taken using online courses at LU. The degree requirement, advisement procedures, courses, and assessment procedures for the $2+2$ online format students are the same as for a traditional transfer student. Given that local students can take online courses and $2+2$ online students can take in-person courses, the $2+2$ online format is not a new or separate degree or 
program, but instead an outreach mechanism for extending a more flexible industrial engineering degree pathway.

A significant number of online courses (15 to 20 per year) have been offered by the Industrial Engineering Department at LU prior to going online with BSIE $2+2$ online. The $2+2$ online option increased the number of courses offered online by nine, including two senior design courses. These earlier online offerings allowed the faculty members in the department to become familiar with online teaching and smoothed the transition to a $2+2$ online offering.

The BSIE $2+2$ option is designed for students who have completed core engineering courses through dynamics and differential equations successfully, but cannot attend a traditional engineering program due to work, location or family commitments. Based on an extensive search, nationwide few online engineering programs exist with no online undergraduate Industrial Engineering programs. University of North Dakota and Arizona State University have online undergraduate engineering programs in a range of engineering disciplines ${ }^{1,2}$. Morgan State and Stony Brook in Electrical Engineering and University of Alabama in Mechanical Engineering have $2+2$ programs online ${ }^{3,4,5}$. Our program in Industrial Engineering is similar to the $2+2$ online programs at other universities in other disciplines.

The rest of the paper is organized as follows. Section 2 discusses the degree plan and course modifications required for online teaching. Section 3 discusses the delivery technology and approaches used to offer online courses. Section 4 discusses the potential market for this program. Section 5 discusses marketing and outreach efforts. Section 5 presents the evaluation results of a student survey about online courses and discuss the progress of our initial cohort of students. Section 6 discusses the reaction of the faculty to the program and incentives for online teaching at LU. Section 7 discusses the impact on accreditation of going online. Section 8 presents key lessons learned to date.

\section{Degree Plan}

Table 1 displays the recommended degree plan for the Freshman and Sophomore years to complete the degree program. The chart uses the Texas standard community college course numbers for the first two years. The department advises students to complete these courses at a community college or university before transferring to LU. While most of the courses are offered online at LU, the full sequence is not offered online as most courses are not from the IE department. The department's website recommends that students should complete at least six math-based lower division courses (such as Calculus I/II, Differential Equations, Linear Algebra, Physics I/II, Chemistry I/II, Statics, Dynamics, Engineering Economics, Circuits, or similar courses) before joining the BSIE $2+2$ online program. The website also recommends that students should have reasonable good grades (mostly A and B) in these math-based lower division courses. While LU has reasonable low transfer admission standards, the department targets students who would have a reasonable high probability of completing a challenging 
distance engineering education program. The degree plan in Table 1 is somewhat typical, but some variation is common (e.g. POLS, HIST, etc. being taken in year 3 or 4 or in summer terms)

Table 1. Recommended year one and two of the degree plan.

\begin{tabular}{|c|c|c|c|}
\hline $\begin{array}{l}\text { FIRST YEAR } \\
\text { Fall }\end{array}$ & & Spring & \\
\hline INEN 1201 Intro to Engineering & 2 & ENGR 2304 Programming for Engrs & 3 \\
\hline CHEM 1311 Chemistry I & 3 & CHEM 1312 - Lab Science Elective (1) & 3 \\
\hline CHEM 1111 Chemistry I Lab & 1 & CHEM 1112 - Lab Science Elective (1) & 1 \\
\hline ENGL 1301 English Composition 1 & 3 & $\begin{array}{l}\text { MATH } 2414 \text { Calculus \& Analytic Geo. } \\
\text { II }\end{array}$ & 4 \\
\hline MATH 2413 Calculus \& Analytic Geo. 1 & 4 & *PHYS 2425 Physics I & 4 \\
\hline PHIL 1370 Philosophy of Knowledge & 3 & & \\
\hline $\begin{array}{l}\text { SECOND YEAR } \\
\text { Fall }\end{array}$ & & Spring & \\
\hline POLS 2301 American Gov't. I & 3 & HIST(1301-2377) History 2 & 3 \\
\hline HIST(1301-1377) History 1 & 3 & ENGR 2305 Circuit Analysis I & 3 \\
\hline *ENGR 2301 Statics & 3 & *MATH 2320 Diff. Eq. & 3 \\
\hline *MATH 2318 Linear Algebra & 3 & *ENGR 2302 Dynamics & 3 \\
\hline *PHYS 2426 Physics II & 4 & $\begin{array}{l}\text { COMM- } \\
1315,1360,2335,2373,3310,3340(4)\end{array}$ & 3 \\
\hline & & POLS 2302 American Gov't. II & 3 \\
\hline
\end{tabular}

*denotes courses not offered online by $L U$.

Table 2 displays the courses taken at LU. The courses with modifications to support online delivery are:

1. INEN 3322 Materials and Manufacturing Processes has a series of manufacturing labs taught over one or two long weekends instead of a whole semester. The weekend lab is supplemented by training videos prior to the lab in lab safety and basic procedures to condense the semester long lab into one weekend.

2. INEN 4345 Computer Integrated Manufacturing and INEN 4375 Simulation employ virtual remote desktops instead of lab computers to provide students with Educational (fully functional) version of PTC Creo and Rockwell Arena. These classes also employ Adobe Connect for live 
software review sessions. These review sessions are similar to the software labs in the on campus courses.

3. INEN 3380 Work Design employs video-based labs instead of live labs.

The other courses did not have significant modifications to be offered online. All online courses can be taken by our traditional students. Many online offerings may also be taught by the same professor who teaches the in-class course.

Table 2. Years 3 and 4 of degree plan.

\begin{tabular}{|c|c|c|c|}
\hline \begin{tabular}{|l} 
THIRD YEAR \\
Fall
\end{tabular} & & Spring & \\
\hline INEN 2373 Engineering Economics & 3 & $\begin{array}{l}\text { INEN } 4320 \text { Stat Decision Making for } \\
\text { Engr }\end{array}$ & 3 \\
\hline INEN 3320 Probability \& Stat for Engr & 3 & $\begin{array}{l}\text { INEN } 4345 \text { Computer Int. } \\
\text { Manufacturing }\end{array}$ & 3 \\
\hline INEN 4315 Industrial Management & 3 & INEN 4370 Operations Research & 3 \\
\hline $\begin{array}{l}\text { INEN } 4350 \text { Production \& Inventory } \\
\text { Control }\end{array}$ & 3 & INEN 4300 Quality Improvement & 3 \\
\hline INEN 3322 Engr. Matls. \& Procs. & 3 & INEN 3380 Work Design & 3 \\
\hline $\begin{array}{l}\text { FOURTH YEAR } \\
\text { Fall }\end{array}$ & & Spring & \\
\hline INEN 4323 IE Systems Design (6) & 3 & INEN 4385 IE Design & 3 \\
\hline INEN 4375 Simulation of IE Sys. & 3 & INEN/TECH Elective (3) & 3 \\
\hline $\begin{array}{l}\text { INEN } 4316 \text { Industrial and Product } \\
\text { Safety }\end{array}$ & 3 & INEN/TECH Elective (3) & 3 \\
\hline INEN/TECH Elective (3) & 3 & Fine Arts Elective (5) & 3 \\
\hline INEN/TECH Elective (3) & 3 & & \\
\hline
\end{tabular}

Having the previously established online Bachelor of Science in Industrial Technology (BSIT) degree program significantly reduced the learning curve in creating the BSIE $2+2$ online offering. Previously establishing the BSIT degree online trained the faculty in online teaching. While INEN 4315 Industrial Management is the only required course that is shared course between the BSIT and BSIE programs, some undergraduate electives including Supply Chain Management, Six Sigma, Lean and Engineering Management are offered online to support both programs. Online offerings from the College of Business provide additional electives in ERP 
using SAP and Project Management with Primavera. Campus wide, at least 3 online electives are offered each term including summer.

Our senior design is a two course sequence (INEN 4323 and INEN 4385). Students in our traditional program solve industry or research problems in teams or individually. Each team is assigned a faculty mentor who meets frequently with the team face to face, online or over the phone. Our traditional students sometimes bring projects from their employers. Beyond the big project, the class also covers design methodology, project management and reviews topics including statistics and engineering economics from prior courses. Prior to going online, the department used mostly team projects but allowed some individual projects.

Two students are taking senior design online in the fall 2015/spring 2016 semesters. One student is studying workforce planning at a major company where the student is employed and the other student is developing a home health medical record system based on a voice-only interface in an exploratory research project. A traditional (not online) student is taking senior design via distance education is exploring developing a software tool for analysis of inventories based on experiences at a major technology company. These projects are similar in scope to traditional senior design projects. The department requires that the projects be separate from the daily job responsibilities and academic in nature, but allows the student to use corporate data. For instances, if a student examined adding a new material handling system where they work, the department project would require an academic risk assessment, an academic economic analysis with simulation, full academic literature review and a full simulation study. The department allows all students to remove highly sensitive information such as pricing data, run rates, yield rates, inventory levels and other similar business confidential information from final submitted reports.

Going online with a $2+2$ online offering has several key advantages over a full online program. The primary advantage is that all courses during the last two years are offered by the IE department, so support from only one department is required. While all general education core courses at LU are offered online, having a full four-year degree would require two Physics courses, two Chemistry courses, four Math Courses, Statics from Civil Engineering, Fundamentals of Electrical Engineering from Electrical Engineering and Dynamics from Mechanical Engineering in addition to the general education requirement. While some of these courses are offered online, having a fully online program would require long term commitments from six departments in two colleges instead of one department to offer online courses. The second advantage is that having all four years online may result in a lower completion rate. Four years in an online program is a long time commitment and engineering programs tends to have a high attrition rate during the first two years. Tyson's study in Florida suggests that completing courses at a community college was not related to greater attrition in engineering, but the performance in the calculus and physics courses was a critical indicator of being able to complete an engineering program ${ }^{6}$. By completing the first two years of an engineering program, student demonstrate the math ability required to complete the courses in the last two years of our program. The final major advantage of $2+2$ online is the lower cost associated with attending 
community college that allows a diverse wide range of students to join these programs. For these reasons, the department has no plans at this time to offer a full 4 year online BSIE degree.

\section{Delivery Technology and Approaches}

The department has a modern suite of software tools for distance education:

- Blackboard for course content management.

- Adobe Connect for video conferencing.

- Mediasite for online lecture video and audio capture.

- Adobe Connect, Microsoft Mix, Screencast-o-matic and other tools for lecture recording.

- Youtube, Adobe Connect, Sorenson and Mediasite for video servers.

- Virtual desktop software implemented by campus IT.

- ProctorU and remote testing services for proctoring.

The department also has a state-of-the-art $(\$ 200,000)$ recording classroom that was completed in September 2014.

A challenge in online program delivery is branding in terms of content delivery mechanism. Generally, all courses should have the same look and operating procedures. Faculty members generally want freedom to design courses and materials based on the technology that they consider best. Without having firm policies, courses will use different technologies and will appear different. Currently, our courses do not have uniform look and operatizing procedures due to using multiple technologies from the above list. Even though this inconsistency has not been an issue to students, aggressive steps are being taken University-wide to address branding. In our program, faculty have considerable flexibility on delivery technology with only guidance on the best practices based on Quality Matters. Quality Matters reviews are optional, but all faculty are instructed to follow the guidelines.

\section{Potential Market}

The potential market for $2+2$ online style program is significant. Texas has 8,879 students enrolled in 2014 at community colleges in Engineering, CIP Code $14010100^{7}$. While this pool is large, only a small subset of the total may be interested in an online program after completing the first two years at community college. Although it is not a requirement most, but not all, of our online $2+2$ students are Texas residents. The quality of community college transfer students is reasonably good with only a slight drop off in academic performance when the students transfer to a 4 year engineering program ${ }^{8}$.

The program has also attracted students who left engineering for non-academic reasons including family responsibilities, employment and starting businesses. The pool of these students is small, but the department has historically had success with this student population. About half of our current online students left other engineering programs for non-academic reasons.

The department anticipated that this program would be relatively small in the beginning. In our first semester, we had four $2+2$ online students. In two years, this number has grown to 
about 15 students. Our plan is to have 10-20 graduates per year who use $2+2$ online the format within 5 years. If this goal is achieved, then online $2+2$ online students will be about half the BSIE students currently graduated by the department.

\section{Marketing}

Marketing of the BSIE $2+2$ has been intentionally limited and primarily done using our website (See http://engineering.lamar.edu/industrial). The number of page views for the $2+2$ online program has been consistent since the website was launched with about 500 views per month. A detailed video on our website describing the program for students has averaged about 50 views per month. About 15-20 prospective students on average contact the department per month. About 3 students per month do a formal inquiry about transfer courses and degree plans per month. About 5 students join the program each semester as $2+2$ students. Most contact with potential students is handled by the IE Chair and, our engineering advising office, and our admissions office.

Transfer students, particularly $2+2$ online students, require a significant amount of advising prior to joining the program. Our current process is for students to contact the IE Chair who replies to each inquiry and directs them to LU's admissions office and college of engineering (COE) advisement office. LU's admissions office reviews each candidate's application and performs the transcript(s) analyses. Only after a student is admitted, LU's COE advisement office creates a degree plan for the student. Each student must apply and be accepted to LU before their transcript(s) are evaluated and a degree plan can be created. However, during this process, the department and the COE advisement office provide general feedback to prospective student questions. Answering the simple question of what is required for a transfer student to graduate often is a labor intensive process especially for students who take courses outside of Texas or take courses at multiple universities.

Formal transfer and articulation relationships with community colleges are another mechanism for student outreach. While we anticipate articulation agreements and outreach to community college students during transfer fairs will work for this program, we have not aggressively employed these outreach activities up to now. However, LU is currently stepping up these articulation agreements and working relationships with community colleges.

The flexibility of having the last two years online is a powerful differentiator for LUIE traditional and non-traditional students who recognize the benefits of flexibility. While we have not determined the impact, anecdotally having the $2+2$ online program allows us to attract students to our traditional four-year program by demonstrating our commitment to online education. Several current students who are not classified as $2+2$ online students selected our traditional program solely due to the flexibility in the last two years. Also, students can use online courses to extend co-op and internships for multiple semesters and the department is generally supportive of students having long term multi-year internships. Most online sections are taught in the same semester with the same professor as the lecture based course. Being a relatively small program, many required courses are only offered once per year, so the online 
courses allow students doing internships to complete prerequisite courses so they do not fall a year out of sequence in the degree plan due to one course.

\section{Student Views of Online Courses}

The department asked 15 questions about online courses as part of our exit interview process. Each question allows free text responses in addition to the Likert response. Question 1 to 13 are prefaced by "For my BSIE courses,". Table 3 displays the responses for 21 students. The number of course online taken by the students ranged from 1 to 8 with an average of 4.1 online courses taken.

Table 3. Exit interview questions about online courses.

\begin{tabular}{|l|c|c|c|c|c|}
\hline Question & Disagree & $\begin{array}{c}\text { Somewhat } \\
\text { Disagree }\end{array}$ & Neutral & $\begin{array}{c}\text { Somewhat } \\
\text { Agree }\end{array}$ & Agree \\
\hline $\begin{array}{l}\text { 1. I feel my level of learning and comprehension was } \\
\text { equivalent in my online and traditional courses }\end{array}$ & 0 & 5 & 2 & 5 & 9 \\
\hline $\begin{array}{l}\text { 2. I feel online and traditional courses offer me an } \\
\text { equivalent amount of flexibility }\end{array}$ & 7 & 3 & 2 & 3 & 6 \\
\hline $\begin{array}{l}\text { 3. I feel course instructors are equally available in } \\
\text { online and traditional courses }\end{array}$ & 0 & 2 & 2 & 0 & 17 \\
\hline $\begin{array}{l}\text { 4. I feel the expectations/requirement were equivalent } \\
\text { for online and traditional courses }\end{array}$ & 0 & 1 & 0 & 4 & 16 \\
\hline $\begin{array}{l}\text { 5. I feel my grade I earned in all courses would have } \\
\text { been the same in regardless of online or traditional } \\
\text { course delivery }\end{array}$ & 2 & 6 & 1 & 2 & 10 \\
\hline $\begin{array}{l}\text { 6. I feel the course expectations are equivalently } \\
\text { clear/unambiguous for online and traditional courses }\end{array}$ & 0 & 0 & 1 & 1 & 19 \\
\hline $\begin{array}{l}\text { 7. I feel the presence or absence of cheating is } \\
\text { equivalent for online and traditional courses }\end{array}$ & 4 & 6 & 0 & 2 & 9 \\
\hline $\begin{array}{l}\text { 8. I feel the computer skills necessary are equivalent } \\
\text { for online and traditional courses }\end{array}$ & 0 & 0 & 1 & 2 & 18 \\
\hline $\begin{array}{l}\text { 9. I feel course time required is equivalent for online } \\
\text { and traditional courses }\end{array}$ & 1 & 6 & 1 & 1 & 12 \\
\hline $\begin{array}{l}\text { 10. I feel that class group projects are equivalent for } \\
\text { online and traditional courses }\end{array}$ & 4 & 3 & 4 & 2 & 8 \\
\hline $\begin{array}{l}\text { 11. I feel the exams are equivalent for online and } \\
\text { traditional sections }\end{array}$ & 1 & 1 & 2 & 4 & 13 \\
\hline $\begin{array}{l}\text { 12. I feel the I can get the equivalent level of course } \\
\text { help/assistance in online and traditional courses }\end{array}$ & 1 & 2 & 2 & 4 & 12 \\
\hline $\begin{array}{l}\text { 13. I feel the workload is equivalent for online and } \\
\text { traditional courses }\end{array}$ & 2 & 1 & 3 & 3 & 12 \\
\hline $\begin{array}{l}\text { 14. I feel all courses in the BSIE program are equally } \\
\text { suited for online course delivery }\end{array}$ & 6 & 4 & 1 & 4 & 6 \\
\hline $\begin{array}{l}\text { 15. Overall, I feel online courses and traditional } \\
\text { courses are equivalent }\end{array}$ & 0 & 1 & 4 & 7 & 9 \\
\hline
\end{tabular}

For Question 1, five respondents out of 21 disagreed that the level of learning was equivalent in online courses. Comments by those respondents suggested that they learned better in lectures, individual professors are weak at online lectures, and they preferred in person classes. For Question 2, all comments suggested that online course provide more flexibility. For Question 5, the majority of comments suggested that online classes were more difficult due to 
tricky multiple choice exams and the requirement for self-paced study on the part of the student. Question 7 suggested that cheating might occur at a higher rate for online courses. This issue has been addressed by requiring proctoring for online tests using a testing center or testing service. Prior to this policy change, some professors used short time window exams with large questions banks as a method for preventing cheating. Future surveys should confirm an improvement in this critical area due to new proctoring requirements. For question 9, six comments suggested online courses required more time and two comments suggested face to face required more time. For Question 10, respondents suggested that online group projects were more difficult due to not meeting your team members face to face. For Question 14, a few students think that hands-on courses with labs and software courses are not as well suited for online delivery. For Question 15 , only one student out of 21 disagreed that online courses were equivalent to traditional courses. While the majority of our students view online course delivery as equivalent to traditional lectures, a few students (about $40 \%$ of the population) do not like online courses. Given that all courses are offered face to face in addition to online, a significant percentage of students take the online offering due to the flexibility even though they might not like the format.

Of the first ten students, half are still enrolled in the program and progressing towards graduation. One student transferred to an on campus program at a different university and one student used the program to improve their Industrial Engineering graduate school application. The students are a diverse mixture of individuals who work full time and stay-at-home parents with small children.

\section{Faculty Reaction}

Going online requires a significant commitment from the faculty. All LUIE faculty members have taught online courses. The faculty are fully supportive of the goal of teaching online courses.

The department and university has employed a carrot approach to encouraging faculty to teach online:

1. Financial Incentive. The Center for Distance Education at Lamar University provides technical support and financial incentives for faculty to develop online courses. While the financial incentives are relatively small (about $\$ 4,500$ per course), the incentives were instrumental in the development of the department's initial online courses. After initial development, smaller incentives exist for teaching online courses.

2. Leadership Support. Our faculty want to document that they are doing projects, including teaching projects that align with the goals of leadership. Faculty members can discuss online course development as part of our annual review and tenure process.

3. Schedule Flexibility. While online courses generally require more work, some faculty members appreciate the flexibility in teaching online courses and have requested online classes especially during the summer term. 
4. Instructors and Adjuncts. The department uses three instructors to help teach our online courses or backfill for professors teaching online courses. The department also uses two highly qualified adjunct instructors who teach three online courses per year. The leadership of the university has been very generous in providing these resources in part to support our online efforts.

5. Overloads. Some faculty members have been scheduled into paid teaching overloads.

A cost benefit analysis is difficult to determine from this program during our launch and growth phase. While online courses have costs, the department has been growing dramatically in part due to our online courses. Once the program matures, a calculation of the costs or excess revenue generated by the offering can be made. Given the relatively small enrollment in the program, we anticipate that the program will not be a huge revenue generator for the university without counting the growth in traditional students attracted by the offering who are not formally $2+2$ online students. Our decision to launch the program was primarily based on a desire to serve students in Texas and beyond.

\section{Accreditation Impact}

The department submitted an interim program modification report to ABET to describe the $2+2$ online offering. The report discussed background information, the need for the program, the degree plan, the resources for delivering the program at both the department and university level, Student Outcome (SO) Assessment, Program Educational Objectives (PEOs), and key performance indicators (KPIs). Outcome assessment for online classes is the same for traditional classes using the same calendar and assessment approaches. Beyond delivery approach and a few modifications to labs, the online program is the same in terms of content as the traditional program.

Beyond our ABET processes, the department will stop or dramatically reengineer this $2+2$ online format if key performance indicators (KPIs) are not meet. These KPIs were discussed in our report to ABET:

1. Student learning outcome achievement meets the minimum standard based on our ABET assessment process.

2. Job placement exceeds $90 \%$ as reported during exit interviews.

3. Starting salary is equivalent to traditional students as reported during exit interviews.

4. Student feedback based on exit interviews is positive about the program.

5. Classroom KPIs based on the indirect measures including student grades and student course evaluations for distance education students are similar to on campus students. These metrics are evaluated during faculty annual reviews.

Prior to LUIE announcing our plans for the BSIE $2+2$ online option, ABET's EAC Executive Committee voted to continue the program's accreditation with the increase in the amount of 
upper division coursework now available through distance delivery based on a review of LUIE program's interim report concerning our program modification.

\section{Lessons Learned}

The primary lesson learned that can be applied by other universities are:

1. Administration support is critical to gaining faculty support for the program and the resources required to run the program.

2. Any online initiative should not have any disincentives for faculty participation. Workload computations should consider online courses at least the same level of effort as in class offerings.

3. Faculty buy in can be achieved with positive incentives.

4. Website marketing works.

5. Online programs can attract students to traditional on-campus programs by providing flexibility for extended internships and full time employment.

\section{Conclusion}

This paper elaborates the Online 2+2 Bachelor's Degree Program Track in Industrial Engineering at Lamar University, first launched in fall 2014. The department is in the second year of this online option. While it is too soon to determine if the program is successful, initial results are positive. The department will continue to study this program to determine if the approach is successful.

\section{References}

1. University of North Dakota (2015). Online degrees. Available at https://und.edu/academics/extendedlearning/online-distance/degrees/. Accessed 12/31/2015.

2. Arizona State University (2015). Online degrees. Available at https://asuonline.asu.edu/online-degreeprograms/undergraduate. Accessed 12/31/2015.

3. Morgan State University (2015). Online degrees. Available at http://www.morgan.edu/online_education/information_for_students/online_courses_and_programs.html. Accessed 12/31/2015.

4. SUNY Stony Brook (2015). Electrical Engineering online degree. Available at http://www.stonybrook.edu/eeonline/. Accessed 12/31/2015.

5. University of Alabama (2015). Mechanical Engineering online degrees. Available at http://bamabydistance.ua.edu/degrees/bs-in-mechanical-engineering-blended/. Accessed 12/31/2015.

6. Tyson, Will (2011). Modeling Engineering Degree Attainment Using High School and College Physics and Calculus Coursetaking and Achievement. Journal of Engineering Education, vol. 100 (4), 760-777.

7. THECB (2015). Texas Higher Education Coordinating Board Declared Majors Report. Available at http://reports.thecb.state.tx.us/approot/dwprodrpt/majmenu.htm. Accessed 12/31/2015.

8. National Academy of Engineering (2015). Workshop on Effective Practices in Supporting Transfer Students. Meeting in Brief, August 2015 